\title{
Evaluation of antimicrobial activity of the endophytic actinomycete R18(6) against multiresistant Gram-negative bacteria
}

\author{
TIELE CARVALHO and SUELI VAN DER SAND \\ Departamento de Microbiologia, Imunologia e Parasitologia, Instituto de Ciências Básicas da Saúde, Universidade \\ Federal do Rio Grande do Sul, Rua Sarmento Leite, 500, sala 216, 90050-170 Porto Alegre, RS, Brasil
}

Manuscript received on December 2, 2014; accepted for publication on February 26, 2015

\begin{abstract}
Endophytic actinomycetes are promising sources of antimicrobial substances. This study evaluates the activity of metabolites produced by the endophytic actinomycete R18(6) against Gram-negative bacteria multiresistant to antimicrobials. R18(6) isolate was grown in submerged cultures under different conditions: carbon source, temperature, $\mathrm{pH}$ and incubation time to optimize antimicrobials production. The actinomycete grown in base medium supplemented with $1 \%$ glucose, $\mathrm{pH} 6.5$ and incubation at $30{ }^{\circ} \mathrm{C}$ for $96 \mathrm{~h}$ with shaking at $100 \mathrm{rpm}$, exhibited the highest activity against the used Gram-negative bacteria. Minimum inhibitory concentration (MIC) of the crude extract produced by the microorganism varied between $1 / 32$ and 1/256. It had bactericide or bacteriostatic activity, depending on the Gram-negative organism. The active extract was stable at high temperatures, and unstable in medium containing proteolytic enzymes. Micromorphology of R18(6) was investigated by optical and scan microscopy, revealing that it was morphologically similar to the genus Streptomyces.
\end{abstract}

Key words: endophytic actinomycetes, Streptomyces, multiresistant Gram-negative bacteria, extract.

\section{INTRODUCTION}

Actinomycetes are Gram-positive bacteria that produce over $60 \%$ of bacterial metabolites, known by the year 2000 (Sosio et al. 2000). A significant portion of these organisms' genome (between $5 \%$ and $10 \%$ ) is used in the production of these metabolites (Baltz 2008), among which antimicrobials stand out. Since 1940, when the first antimicrobial agent was isolated from the genus Streptomyces, actinomycetes have become the main sources of active metabolites.

Correspondence to: Sueli Van Der Sand

E-mail: svands@ufrgs.br
These bacteria play an important role in the rhizosphere. They have considerable influence in plant growth, protecting roots from pathogenic microorganisms and environmental factors (Hasegawa et al. 2006). Some species establish a specific relationship with plant tissues, and are called endophytic actinomycetes (Crawford et al. 1993). The benefit that this relationship represents to plants may result from the production of secondary compounds by these microorganisms. These metabolites may be phytohormones, antibiotics, and siderophores, which act directly on the plant metabolism or affect pathogenic agents by antibiosis or competition (Hasegawa et al. 2006). 
The economic relevance of the genus Streptomyces lies in the production of active metabolites. The production of secondary metabolites that have considerable biological activity places the genus in an important position, amidst other genera of actinomycetes (Bérdy 2005, Bibb 2005). For example, around $80 \%$ of the antimicrobials currently known are produced by Streptomyces species (Prabavathy et al. 2006).

Despite the wide variety of antimicrobials available, the indiscriminate use of these compounds promotes the emergence of resistant microorganisms. Resistance to antimicrobials is a complex problem, which depends on several factors such as the microorganisms themselves, the medicament used, and the environment (Monroe and Polk 2000).

In this scenario, the present study evaluates the potential of the endophytic actinomycete R18(6) to produce active metabolites against multiresistant Gram-negative bacteria isolated in clinical and natural environments. Additionally, growth conditions were optimized for the production of active metabolites by the bacterium, which were characterized based on stability against proteolytic enzymes and temperature variation.

\section{MATERIALS AND METHODS}

THE ACTINOMYCETE

The endophytic actinomycete R18(6) analyzed, was isolated from the roots of the tomato plant, Lycopersicon esculentum (Oliveira et al. 2010). The sample was recovered in dishes containing casein starch agar (CSA) (1\% starch, $0.12 \%$ casein, $0.2 \% \mathrm{NaCl}, 0.2 \% \mathrm{KNO}_{3}, 0.2 \% \mathrm{~K}_{2} \mathrm{HPO}_{4}, 0.005 \%$ $\mathrm{MgSO}_{4}, 0.001 \% \mathrm{FeSO}_{4}, 0.002 \% \mathrm{CaCO}_{3}, 0.6 \%$ bacteriological agar) and incubated at $30{ }^{\circ} \mathrm{C}$ for 10 days.

\section{GRAM-NEGATIVE ISOLATES}

Twenty-two Gram-negative bacteria (Table I), stored in glycerol $20 \%$, were recovered in trypticase soy agar (TSA) at $35^{\circ} \mathrm{C}$ for $24 \mathrm{~h}$ and used to assess the antimicrobial activity of the extract produced by R18(6).

\section{SUSCEPTIBILITY PROFILE OF BACTERIAL ISOLATES TO ANTIMICROBIALS}

The Gram-negative bacteria used were analyzed to develop an antibiogram using the KirbyBauer method (CLSI 2009). Inhibition halos were interpreted following the standard method M100-S22 (CLSI 2012). The antimicrobials used $(n=20)$ belonged to the classes most commonly prescribed in treatments against Gram-negative bacteria: Amoxicillin/clavulanate (AMC $10 \mu \mathrm{g}$ ), ampicillin (AMP $10 \mu \mathrm{g}$ ), aztreonam (ATM $30 \mu \mathrm{g}$ ), ceftazidime (CAZ $30 \mu \mathrm{g}$ ), cephalothin (CFL 30 $\mu \mathrm{g}$ ), cefoxitin (CFO $30 \mu \mathrm{g}$ ), ciprofloxacin (CIP 5 $\mu \mathrm{g}$ ), chloramphenicol (CLO $30 \mu \mathrm{g}$ ), cefpodoxime (CPD $10 \mu \mathrm{g}$ ), ceftriaxone (CRO $30 \mu \mathrm{g}$ ), cefotaxime (CTX $30 \mu \mathrm{g}$ ), ertapenem (ETP $10 \mu \mathrm{g}$ ), streptomycin (EST $10 \mu \mathrm{g}$ ), gentamicin (GEN $10 \mu \mathrm{g}$ ), imipenem (IMP $10 \mu \mathrm{g}$ ), meropenem (MER $10 \mu \mathrm{g}$ ), nitrofurantoin (NIT $300 \mu \mathrm{g}$ ), norfloxacin (NOR 10 $\mu \mathrm{g}$ ), sulfamethoxazole/trimethoprim (SUT $25 \mu \mathrm{g}$ ), tetracycline (TET $30 \mu \mathrm{g}$ ). Multiresistance of Gramnegative bacteria was defined as the resistance to, at least, three different classes of antimicrobials.

\section{OPTIMIZATION OF GROWTH CONDITIONS}

The influence of the parameters in different growth culture conditions was assessed in order to enhance the production of active metabolites by R18(6) during growth. Four carbon sources were used (starch, saccharose, glycerol, and glucose) in 1\% base medium $(0.03 \%$ casein, $0.2 \% \mathrm{NaCl}, 0.2 \%$ $\mathrm{K}_{2} \mathrm{HPO}_{4}, 0.005 \% \mathrm{MgSO}_{4}, 0.002 \% \mathrm{CaCO}_{3}, 0.2 \%$ $\mathrm{KNO}_{3}$ ). After the determination of the optimal carbon source for the production by R18(6) of a crude extract that exhibited the best antimicrobial activity, the influence of incubation temperature was evaluated. Five temperatures were used (30 ${ }^{\circ} \mathrm{C}, 35^{\circ} \mathrm{C}, 40{ }^{\circ} \mathrm{C}$, and $45^{\circ} \mathrm{C}$ ). After, ideal $\mathrm{pH}$ was 
established using $\mathrm{pH}$ values of 4.0, 4.5, 5.0, 6.0, $6.5,7.0$, and $8.0, \mathrm{pH}$ values of the growth medium were adjusted with the buffers McIllvaine $(\mathrm{pH}$ 4.0 and 5.0), acetic acid and acetate ( $\mathrm{pH} 4.5)$, potassium phosphate and sodium hydroxide $(\mathrm{pH}$ 6.0, 7.0, and 8.0), and sodium phosphate ( $\mathrm{pH}$ 6.5) (Assumpção and Morita 1968). Incubation times for the production of active R18(6) metabolite extract were also assessed every $24 \mathrm{~h}$ during the 10-day incubation period.

Production OF THE CRUde EXTRACT IN SUbMERGED Culture

Initially, a pre-inoculum was prepared transferring a loopful of R18(6), previously grown in a CSA dish to two $250-\mathrm{mL}$ flasks containing $50 \mathrm{~mL}$ base medium supplemented with $1 \%$ glucose. Contents were then incubated at $30{ }^{\circ} \mathrm{C}$ for $48 \mathrm{~h}$ with constant shaking $(100 \mathrm{rpm})$. Next, three $\mathrm{mL}$ of this preinoculum were transferred to new flasks containing the same culture medium. The growth conditions for R18(6) were the same as those used to prepare the pre-inoculum. During the 10-day incubation period, a $100-\mu \mathrm{L}$ aliquot was retrieved every $24 \mathrm{~h}$, centrifuged (10 min; 13,000 rpm), and used in the antibiosis assay by the agar well diffusion method.

\section{ANTIBIOSIS ASSAY BY THE AGAR WELl DIFFUSION} METHOD

The antibiosis assay was adapted from Devillers et al. (1989). A bacterial suspension was adjusted to $0.5 \mathrm{McF}$ arland standard $\left(10^{8} \mathrm{CFU} / \mathrm{mL}\right)$ and inoculated into Petri dish containing MuellerHinton agar. After seeding, wells were made on agar, using cylinders measuring $9 \mathrm{~mm}$ in diameter at identical distances across one another, and filled with $100 \mu \mathrm{L}$ of the extract previously centrifuged for $10 \mathrm{~min}$ at 13,000 rpm. Dishes were incubated at $4{ }^{\circ} \mathrm{C}$ for $16 \mathrm{~h}$, for the extract to diffuse in the culture medium. Subsequently, incubation at $35^{\circ} \mathrm{C}$ for $24 \mathrm{~h}$ ensued, for bacterial growth. Antimicrobial activity was measured based on inhibition halos. All assays were carried out in duplicate. The results were analyzed using the analysis of variance (ANOVA) and the Tukey test for comparison of multiple means at $95 \%$ significance.

\section{GROWTH CURVE OF R18(6)}

A growth curve was constructed to evaluate growth time of R18(6) and correlate it with the production phase of the active metabolite extract. R18(6) was grown in submerged culture for ten days under the conditions described above as optimal for the production of active metabolite extract against Gram-negative isolates. The growth medium in one flask was filtered through a $0.45-\mu \mathrm{m}$ porosity cellulose membrane, every $24 \mathrm{~h}$ during the 10 day growth period. Dry weight of cell mass was established on the difference between the final weight of the membrane, after filtration, and the initial weight.

MINIMUM INHIBITORY CONCENTRATION (MIC)

Minimum inhibitory concentration (MIC) was determined using the micro-dilution method in broth, according to the standard method (M7-A7 (CSLI 2006). Incubation took place at $35^{\circ} \mathrm{C}$ for $24 \mathrm{~h}$ and $48 \mathrm{~h}$. Seventeen Gram-negative isolates (Table I) were used. MIC was defined as the lowest concentration of the R18(6) crude extract able to inhibit bacterial growth.

EFFECT OF DIFFERENT TREATMENTS ON THE ACTIVITY OF R18(6) EXTRACT

The active metabolites present in the R18(6) extract were partially characterized based on the stability of proteolytic enzymes and different incubation temperatures. The stability against enzymes was evaluated treating the crude extract with $2 \%$ (final concentration) of trypsin $(25 \mathrm{mg} / \mathrm{mL})$, papain $(100$ $\mathrm{mg} / \mathrm{mL})$, proteinase $\mathrm{K}(50 \mathrm{mg} / \mathrm{mL})$, lysozyme (50 $\mathrm{mg} / \mathrm{mL})$, and pepsin $(100 \mathrm{mg} / \mathrm{mL})$ solutions. All reactions were carried out in microtubes. Incubation conditions were $37^{\circ} \mathrm{C}$ for $1 \mathrm{~h}$. 
TABLE I

Gram-negative bacteria used in this study.

\begin{tabular}{|c|c|}
\hline Environmental isolates $^{1}$ & Clinical isolates $^{2}$ \\
\hline Citrobacter koseri 3CC04* & Citrobacter freundii $17^{*}$ \\
\hline Citrobacter koseri 3EC04 & Enterobacter cloacae 49* \\
\hline Citrobacter freundii $1 \mathrm{CC} 09^{*}$ & Enterobacter cloacae $62 *$ \\
\hline Pantoea agglomerans 3AE03 & Escherichia coli $70^{*}$ \\
\hline Enterobacter intermedius $1 \mathrm{CC} 07$ & Klebsiella oxytoca $90^{*}$ \\
\hline Escherichia coli $1 \mathrm{DE} 14 *$ & Klebsiella pneumonia $15^{*}$ \\
\hline Escherichia coli 4EC05 & Klebsiella pneumoniae $222 *$ \\
\hline Klebsiella pneumonia 1CE02* & Morganella morganii $162^{*}$ \\
\hline Klebsiella oxytoca 2BS08 & Proteus mirabilis $102 *$ \\
\hline \multirow[t]{3}{*}{ Proteus mirabilis 3DC01* } & Pseudomonas aeruginosa 54* \\
\hline & Pseudomonas aeruginosa 59* \\
\hline & Pseudomonas aeruginosa $230 *$ \\
\hline
\end{tabular}

${ }^{1}$ Samples isolated from the waters of Diluvio stream, Porto Alegre, RS, Brazil (Oliveira et al. 2012). ${ }^{2}$ Samples provided by Dr. Ana Lucia Souza Antunes, Laboratory of Analysis, Faculdade de Farmácia, Universidade Federal do Rio Grande do Sul, RS, Brazil.

*Isolates used in the MIC assay.

Thermostability was analyzed at $30{ }^{\circ} \mathrm{C}, 40{ }^{\circ} \mathrm{C}$, $50{ }^{\circ} \mathrm{C}, 60{ }^{\circ} \mathrm{C}, 70{ }^{\circ} \mathrm{C}, 80{ }^{\circ} \mathrm{C}, 90^{\circ} \mathrm{C}$, and $100{ }^{\circ} \mathrm{C}$ in a water bath. Incubation times chosen for the assays at the temperatures ranging from $30{ }^{\circ} \mathrm{C}$ to $90{ }^{\circ} \mathrm{C}$ were $15 \mathrm{~min}$ and $30 \mathrm{~min}$. Stability at $100{ }^{\circ} \mathrm{C}$ was evaluated for $3 \mathrm{~min}, 5 \mathrm{~min}, 10 \mathrm{~min}, 15 \mathrm{~min}$, and 30 $\mathrm{min}$. Antimicrobial activity of the active metabolites after treatment was evaluated using the well diffusion method against the bacterium Klebsiella pneumonia 222. The crude extract was the positive control. The tests were conducted in duplicate, the inhibition halos were measured and the residual activity (RA) of metabolites was calculated using the equation adapted from Oliveira (2004):

$$
\mathrm{RA}(\%)=\left(\mathrm{H}_{\mathrm{T}}-9\right) /\left(\mathrm{H}_{\mathrm{C}}-9\right) \times 100
$$

Where,

$\mathrm{H}_{\mathrm{T}}=$ Mean inhibition halo of crude extract after treatment $(\mathrm{mm})$

$\mathrm{H}_{\mathrm{C}}=$ Mean inhibition halo of the control ( $\mathrm{mm}$ )

$9=$ diameter of the well $(\mathrm{mm})$

MORPHOLOGICAL CHARACTERIZATION OF R18(6)

The micro-morphology of R18(6) was characterized by microscopy. The attributes of the aerial mycelium and hyphae were observed in an optical microscope. The morphology of hyphae and the surface of spores was assessed by scanning electron microscopy (SEM) (Williams et al. 1989). Microcultive was carried out in CSA for ten days and four days, for optical microscopy and SEM analysis, respectively, at $30^{\circ} \mathrm{C}$.

\section{RESULTS}

Of the Gram-negative isolates used, 64\% were multiresistant to the antimicrobials used in the assay (Table SI - Supplementary Material). Based on these findings, one multiresistant isolate from each species was chosen for the assays to determine optimal growth conditions for the production of active metabolites by R18(6) (Table SI).

The extract produced with the growth of $\mathrm{R} 18(6)$ in the presence of glucose as a carbon source was active against $89 \%$ of the Gramnegative bacteria, among them the exception was E. intermedius $1 \mathrm{CC} 07$. In turn, the extract obtained with glycerol was active against four isolates: $E$. intermedius $1 \mathrm{CC} 07, \mathrm{~K}$. oxytoca 90, C. freundii 17, and $K$. pneumoniae 222 with inhibition halos of 
$15 \mathrm{~mm}, 16 \mathrm{~mm}, 18 \mathrm{~mm}$, and $16 \mathrm{~mm}$, respectively. The use of saccharose as a carbon source produced metabolites that were effective against $C$. freundii 17 and $K$. pneumoniae 222, with inhibition halos of $13 \mathrm{~mm}$ and $17 \mathrm{~mm}$. The active metabolite extract produced using starch was active against one isolate only: K. oxytoca 90 (15 mm).

The metabolite extract produced at $30^{\circ} \mathrm{C}$ was active against 8 of the 9 Gram-negative bacteria $(89 \%)$ with significant differences from the other isolates when grown at $35{ }^{\circ} \mathrm{C}$ (Table II). At $40{ }^{\circ} \mathrm{C}$ and $45^{\circ} \mathrm{C}$, no cell mass growth was observed, and extracts did not exhibit antimicrobial activity. The extract produced at $25^{\circ} \mathrm{C}$ was active only against $E$. cloacae 62 , with inhibition halo of $12.5 \mathrm{~mm}$.

TABLE II

Results of the optimization of the production of active R18(6) metabolites using glucose as carbon source (incubation temperatures of $30^{\circ} \mathrm{C}$ and $35^{\circ} \mathrm{C}$ ).

\begin{tabular}{lcc}
\hline \multirow{2}{*}{ Gram-negative bacteria } & \multicolumn{2}{c}{ Mean inhibition halos $(\mathrm{mm})$} \\
\cline { 2 - 3 } & $30^{\circ} \mathrm{C}$ & $35^{\circ} \mathrm{C}$ \\
\hline E. intermedius 1CC07 & 16.0 & 13.0 \\
C. koseri 3CC04 & 17.0 & 12.0 \\
K. oxytoca 90 & 17.5 & 13.0 \\
E. coli 70 & 16.0 & 0.0 \\
E. cloacae 62 & 16.0 & 0.0 \\
M. morganii 162 & 14.5 & 0.0 \\
P. aeruginosa 54 & 0.0 & 0.0 \\
C. freundii 17 & 17.3 & 0.0 \\
K. pneumoniae 222 & 19.2 & 14.0 \\
\hline
\end{tabular}

The medium buffered at $\mathrm{pH} 6.5$ was used in the other assays, since the metabolite extract produced under this condition was active against $100 \%$ of Gram-negative bacteria, compared with $\mathrm{pH}$ values of $6.0,7.0$, and 8.0 (data not shown). In turn, R18(6) did not grow at $\mathrm{pH} 4.0,4.5$, and 5.0.

The metabolic activity of the extracts, was incubated for $72 \mathrm{~h}, 96 \mathrm{~h}, 120 \mathrm{~h}$, and $168 \mathrm{~h}$ and did not vary significantly when the Tukey test was applied (Table III). However, when cells were grown for $96 \mathrm{~h}$, the extract was active against the highest number of Gram-negative isolates. The
Gram-negative bacteria were not inhibited when the actinomycete was incubated for $24 \mathrm{~h}, 48 \mathrm{~h}$, $144 \mathrm{~h}$, and $192 \mathrm{~h}$, though cell mass increased. Incubation times of $216 \mathrm{~h}$ produced metabolites that were active against $C$. freundii 17 and after 240 $\mathrm{h}$ of growth, the metabolites were active against three isolates: E. intermedius $1 \mathrm{CC} 07, P$. aeruginosa 54, K. pneumoniae 222.

The growth curve showed that the R18(6) reached steady-state growth with incubation time of $72 \mathrm{~h}$ and longer.

In the MIC assay, the metabolite extract concentration was $1 / 32,1 / 64$, and $1 / 128$ after $24 \mathrm{~h}$ of incubation for $K$. pneumoniae $15, C$. freundii 17 , and E. cloacae 49, respectively. When incubated for 48 h, E. cloacae 49 grew in all dilutions used, while isolates $C$. freundii 17 and $K$. pneumoniae $15 \mathrm{did}$ not grow at the $1 / 32$ dilution. The isolates $K$. oxytoca, C. koseri, E. coli, P. mirabilis, and P. aeruginosa grew in all dilutions of R18(6) metabolite extract (Table IV).

The enzyme activity assay showed that R18(6) metabolite extract retained $94 \%, 82 \%$, and $77 \%$ of the antimicrobial activity after treatment with trypsin, papain and lysozyme, and proteinaseK, respectively. The statistical analysis revealed that treatments with the enzymes differed significantly. Treatment with pepsin completely inhibited antimicrobial activity of R18(6) metabolite extract.

The residual activity of the extract treated at the temperature range $30{ }^{\circ} \mathrm{C}-90^{\circ} \mathrm{C}$ varied between $47 \%$ and $88 \%$. After an incubation at $80{ }^{\circ} \mathrm{C}$ for 15 min, activity decreased. At $90^{\circ} \mathrm{C}$ for $30 \mathrm{~min}$, residual activity dropped to $47 \%$. When treated at $100^{\circ} \mathrm{C}$ for $3 \mathrm{~min}$, the extract retained $82 \%$ of activity, which dropped to $0 \%$ after $30 \mathrm{~min}$ of incubation.

Optical microscopy and SEM of the microgrowth of R18(6) showed the presence of aerial mycelia and spiral terminal chains of spores with septate hyphae and smooth spores. These characteristics may indicate that the microorganism may be from the Streptomyces genus. 
TABLE III

Results of the optimization of the production of active R18(6) metabolites using $1 \%$ glucose as carbon source and different incubation times.

\begin{tabular}{|c|c|c|c|c|c|}
\hline \multirow{2}{*}{\multicolumn{2}{|c|}{ Gram-negative bacteria }} & \multicolumn{4}{|c|}{ Incubation time / mean inhibition halos $(\mathrm{mm})$} \\
\hline & & \multirow{2}{*}{$\frac{72 \mathrm{~h}^{\mathrm{a}, \mathrm{c}}}{0.0}$} & \multirow{2}{*}{$\frac{96 \mathrm{~h}^{\mathrm{a}}}{0.0}$} & \multirow{2}{*}{$\begin{array}{c}120 \mathrm{~h}^{\mathrm{a}, \mathrm{b}} \\
0.0\end{array}$} & \multirow{2}{*}{$\frac{168 \mathrm{~h}^{\mathrm{a}, \mathrm{c}}}{12.8}$} \\
\hline E. intermedius & $1 \mathrm{CC} 07$ & & & & \\
\hline C. koseri & $3 \mathrm{CC} 04$ & 12.3 & 13.5 & 0.0 & 14.5 \\
\hline K. oxytoca & 90 & 12.8 & 14.0 & 13.3 & 0.0 \\
\hline E. coli & 70 & 15.5 & 15.3 & 0.0 & 13.5 \\
\hline E. cloacae & 62 & 12.3 & 14.5 & 13.3 & 13.5 \\
\hline M. morganii & 162 & 13.8 & 13.5 & 0.0 & 0.0 \\
\hline P. aeruginosa & 54 & 0.0 & 13.8 & 12.0 & 17.0 \\
\hline C. freundii & 17 & 0.0 & 17.5 & 13.5 & 0.0 \\
\hline K. pneumoniae & 222 & 15.8 & 21.0 & 15.0 & 16.5 \\
\hline
\end{tabular}

Identical letters show no statistically significant differences between treatments (Tukey test, $\mathrm{p}>0.05$ ).

TABLE IV

Results of the minimum inhibitory concentration (MIC) of the crude extract produced by the endophytic actinomycete R18(6) against environmental and clinical samples after $24 \mathrm{~h}$ of incubation.

\begin{tabular}{|c|c|c|c|c|c|c|c|c|c|c|c|}
\hline \multirow{2}{*}{ Gram-negative bacteria } & \multicolumn{11}{|c|}{ Metabolite extract concentration } \\
\hline & Extract & $1 / 2$ & $1 / 4$ & $1 / 8$ & $1 / 16$ & $1 / 32$ & $1 / 64$ & $1 / 128$ & $1 / 256$ & $1 / 512$ & $1 / 1024$ \\
\hline \multicolumn{12}{|l|}{ Environmental Samples } \\
\hline K. pneumoniae 1CE02 & + & + & + & + & + & + & + & + & + & + & + \\
\hline C. koseri $3 \mathrm{CC} 04$ & + & + & + & + & + & + & + & + & + & + & + \\
\hline E.coli $1 \mathrm{DE} 14$ & + & + & + & + & + & + & + & + & + & + & + \\
\hline C. freundii $1 \mathrm{CC} 09$ & + & + & + & + & + & + & + & + & + & + & + \\
\hline P. mirabilis $3 \mathrm{DC} 01$ & + & + & + & + & + & + & + & + & + & + & + \\
\hline \multicolumn{12}{|l|}{ Clinical Samples } \\
\hline K. pneumoniae 15 & - & - & - & - & - & - & + & + & + & + & + \\
\hline K. pneumoniae 222 & + & + & + & + & + & + & + & + & + & + & + \\
\hline K. oxytoca 90 & + & + & + & + & + & + & + & + & + & + & + \\
\hline E.coli 70 & + & + & + & + & + & + & + & + & + & + & + \\
\hline E. cloacae 62 & + & + & + & + & + & + & + & + & + & + & + \\
\hline E. cloacae 49 & - & - & - & - & - & - & - & - & + & + & + \\
\hline C. freundii 17 & - & - & - & - & - & - & - & + & + & + & + \\
\hline P. mirabilis 102 & + & + & + & + & + & + & + & + & + & + & + \\
\hline M. morganii 162 & + & + & + & + & + & + & + & + & + & + & + \\
\hline P. aeruginosa 54 & + & + & + & + & + & + & + & + & + & + & + \\
\hline P. aeruginosa 59 & + & + & + & + & + & + & + & + & + & + & + \\
\hline P. aeruginosa 230 & + & & & & & & & & & & \\
\hline
\end{tabular}

+ : positive cell growth, - : negative cell growth.

\section{DISCUSSION}

The susceptibility profiles of Gram-negative bacteria showed that $64 \%$ of isolates were resistant to, at least, three different classes of antimicrobials.
The multiresistance presented by these isolates may be associated with resistance mechanisms such as: enzyme inactivation and efflux pumps, among others (Sundsfjord et al. 2004, Weber and Piddock 2003). Gram-negative bacteria, mainly 
Escherichia coli, Klebsiella sp., Enterobacter sp., and Pseudomonas sp., are often reported to be multiresistant microorganisms (Pagès et al. 2008).

The extract produced by R18(6) during the growth in a medium containing glucose as a carbon source stood out, compared to other carbon sources used. This was probably due to the antibiotic activity against the largest number of Gramnegative bacteria. These results show that the synthesis of active compounds by microorganisms is not steady and can be adjusted by modifying the culture conditions (Al-Zahrani 2007). Previous studies analyzed the influence of different carbon sources, and discovered that a glucose medium favors the production of active metabolites (Gupte and Kulkarni 2002, Sujatha et al. 2005, Al-Zahrani 2007).

Confirming the findings in the literature (Elleuch et al. 2010, Sujatha et al. 2005, Selvin et al. 2009), $30{ }^{\circ} \mathrm{C}$ was the ideal temperature to cultivate $\mathrm{R} 18(6)$ and to optimize the production of active metabolites since the extract produced, exhibited the highest antimicrobial activity against Gram-negative bacteria.

$\mathrm{pH}$ is one of the most important parameters of culture media, as it directly influences activity of several enzymes that plays an essential role in the metabolism of microorganisms (Guimarães et al. 2004). This relationship was observed in the present study, since the extract produced at $\mathrm{pH}$ 6.5 was active against $100 \%$ of Gram-negative bacteria.

Incubation time of $96 \mathrm{~h}$ of R18(6) afforded the production of the extract with the highest antibiotic activity. Banga et al. (2008) and Sujatha et al. (2005) analyzed the production of active metabolites by isolates of Streptomyces sp., observing that the maximum amount of antibiotics was produced by cultures grown for $96 \mathrm{~h}$.

The growth curve of $\mathrm{R} 18(6)$ revealed that steady-state growth started with $72 \mathrm{~h}$ of incubation. The fact that the $96 \mathrm{~h}$ incubation time was considered the best is related to the fact that the metabolite was active against the highest number of Gramnegative bacteria. This result allows suggesting that the active metabolite is a product of secondary metabolism. According to Bibb (2005), the limited nutrient availability during steady-state growth promotes the formation of secondary metabolites that are required for microorganism survival.

The analysis of the MIC showed that the extract dilutions $1 / 128$ and $1 / 256$ exerted bacteriostatic activity against $E$. cloacae 49 . The same finding was observed for isolates $C$. freundii 17 and $K$. pneumonia 15 , challenged with the $1 / 32$ and $1 / 64$ extract dilutions. The comparison between MICs of isolates of the same species revealed differences in inhibition power of the R18(6) extract. This may be due to the differences in susceptibility profiles and resistance mechanisms. The isolates $K$. oxytoca, C. koseri, E. coli, P. mirabilis, and P. aeruginosa were not inhibited in this assay, indicating that the extract may have lost its inhibitory power, due to dilution, or because it was not purified.

The extract exhibited residual activity after treatment with trypsin, papain, lysozyme, and proteinase K, but not with pepsin. These enzymes are endopeptidases that cleave peptide bonds that are distant from terminal carboxyl and amine groups (Bender and Kézdy 1965, Chipman and Sharon 1969, Ebeling et al. 1974). Pepsin is a proteinase responsible for the cleaveage of peptide bonds formed by the aromatic amino acids tyrosine and phenylalanine (Fruton et al. 1961, Knowles 1970). The evaluation of stability against proteolytic enzymes showed that the active metabolite has peptide bonds that, when hydrolyzed, lead to the loss of activity. Pei et al. (2013) evaluated the stability of the bacteriocine produced by Lactobacillus paracasei CICC 20241 against several enzymes (proteinase $\mathrm{K}$, pepsin, papain, trypsin, and chimiotrypsin). The authors observed that activity of the metabolite was thoroughly inhibited by the 
five enzymes, showing that a peptidic portion is responsible for the activity.

The residual activity of R18(6) extract after incubation at $80^{\circ} \mathrm{C}$ for 15 min was $88 \%$. This result suggests that the extract may be exposed to temperatures of up to $80^{\circ} \mathrm{C}$, without losing much of its activity. In turn, the activity of the extract heated to $100{ }^{\circ} \mathrm{C}$ started decrease with 3 min of incubation, dropping progressively until complete inactivation, with $30 \mathrm{~min}$ of incubation. This result indicates that the chemical structure of active compounds present in the crude extract does not tolerate higher temperatures for long periods of time. Thermal stability of protein molecules may be associated with intrinsic factors concerning their primary and secondary structures such as for example, the presence of disulfide bonds, for instance, which favor the stabilization of the molecule (Gomes et al. 2007, Pei et al. 2013).

The micromorphology of R18(6) was characterized. It indicated that the actinomycete belongs to the genus Streptomyces, since it presents an aerial mycelium with a spiral terminal spore chains, apart from septate hyphae and smooth spores, which are typical of the genus (Williams et al. 1989).

The findings reported here show that the endophytic actinomycete R18(6) is a potential candidate for the production of active metabolites against multiresistant Gram-negative bacteria. However, more studies are necessary, with regard to the purification and characterization of the components of R18(6) extract that exhibit antibiotic activity.

\section{ACKNOWLEDGMENTS}

We would like to thanks Conselho Nacional de Desenvolvimento Científico e Tecnológico (CNPq) for the scholarship and Coordenação de Aperfeiçoamento de Pessoal de Nível Superior (CAPES) for the financial support.

\section{RESUMO}

Os actinomicetos endofíticos são promissoras fontes de compostos antimicrobianos. Este estudo avaliou a atividade dos metabólitos produzidos pelo actinomiceto endofítico R18(6) contra bactérias Gram-negativas multirresistentes a antimicrobianos. O isolado R18(6) foi cultivado em culturas submersas sob diferentes condições: fonte de carbono, temperatura, $\mathrm{pH}$ e tempo de incubação para otimização da produção do composto. $\mathrm{O}$ actinomiceto cultivado em meio base suplementado com $1 \%$ de glicose, $\mathrm{pH} 6.5$ e incubação a $30{ }^{\circ} \mathrm{C}$ sob agitação constante de $100 \mathrm{rpm}$ durante $96 \mathrm{~h}$, mostrou a melhor atividade contra as bactérias Gram-negativas testadas. A concentração inibitória mínima produzida pelo microorganismo variou entre 1/32 e 1/256. Revelou atividade bactericida ou bacteriostática de acordo com o isolado Gram-negativo. O extrato ativo mostrouse estável em altas temperaturas e instável em meio contendo enzimas proteolíticas. A micromorfologia R18(6) foi avaliada, sob microscopia óptica e de varredura revelando que era morfologicamente similar ao gênero Streptomyces.

Palavras-chave: actinomicetos endofíticos, Streptomyces, bactérias Gram-negativas multirresistentes, extrato.

\section{REFERENCES}

AL-ZAHRANI SHM. 2007. Studies of the antimicrobial activity of Streptomyces sp. isolated from Jazan. J King Abdulaziz Uni Sci 19: 127-138.

ASSUMPÇÃO RMV AND MORITA T. 1968. Manual de Soluções, Reagentes e Solventes. Padronizações, preparação e purificação, Edgar \& Blücher Ltda, São Paulo. Volume 1, p. 449.

BALTZ RH. 2008. Renaissance in antibacterial discovery from actinomycetes. Curr Opin Pharmacol 8: 557-563.

BANGA J, PRAVEEN V, SINGH VI, TRIPATHI CKM AND BIHARI V. 2008. Studies on medium optimization for the production of antifungal and antibacterial antibiotics from a bioactive soil actinomycete. Med Chem Res 17: 425-436.

BENDER ML AND KÉZDY FJ. 1965. Mechanism of action of proteolytic enzymes. Annu Rev Biochem 34: 49-76.

BÉRDY J. 2005. Bioactive microbial metabolites. J Antibiot 58: $1-26$.

BIBB MJ. 2005. Regulation of secondary metabolism in streptomycetes. Curr Opin Microbiol 8: 208-215.

CHIPMAN DM AND SHARON N. 1969. Mechanism of lysozyme action. Science 165: 454-465.

CLSI - CLINICAL AND LABORATORY STANDARDS INSTITUTE. 2006. Clinical and Laboratory Standards Institute. 
Methods for dilution antimicrobial susceptibility tests for bacteria that grow aerobically Approved standard. $7^{\text {th }}$ ed., 26: M7-A7.

CLSI - CLINICAL AND LABORATORY STANDARDS INSTITUTE. 2009. Clinical and Laboratory Standards Institute. Performance standards for antimicrobial disk susceptibility tests; Approved standard. 10 ${ }^{\text {th }}$ ed., 29: M02-A10.

CLSI-CLINICAL AND LABORATORY STANDARDS INSTITUTE. 2012. Clinical and Laboratory Standards Institute. Performance standards for antimicrobial susceptibility testing. 22 Information supplement 32: M100-S22.

CRAWFORD DL, LYNCH JM, WHIPPS JM AND OUSLEY MA. 1993. Isolation and characterization of actinomycete antagonists of a fungal root pathogen. Appl Environ Microbiol 59: 3899-3905.

Devillers J, Steiman R AND Seigle-Murandi F. 1989. The usefulness of the agar-well diffusion method for assessing chemical toxicity to bacteria and fungi. Chemosphere 19: 1693-1700.

Ebeling W, HennRich N, Klockow M, Metz H, ORTH HD AND LANG H. 1974. Proteinase K from Tritirachium album Limber. Eur J Biochem 47: 91-97.

Elleuch L, ShaAban M, Smaoui S, Mellouli L, KARRAY-REBAI I, FGUIRA LF, SHAABAN KA AND LAATSCH H. 2010. Bioactive secondary metabolites from a new terrestrial Streptomyces sp. TN262. Appl Biochem Biotechnol 162: 579-593.

FRUTON JS, FUJIIT S AND KNAPPENBERGER MH. 1961. The mechanism of pepsin action. Proc Nat Acad Sci 47: 159761.

Gomes E, GUEz MAU, MARTIN N AND Silva R. 2007. Enzimas termoestáveis: fontes, produção e aplicação industrial. Quím Nova 30: 136-145.

GUIMARÃES LM, FURLAN RLA, GARRIDO LM, VENTURA A, PADILLA G AND FACCIOTTI MCR. 2004. Effect of $\mathrm{pH}$ on the production of the antitumor antibiotic retamycin by Streptomyces olindensis. Biotechnol Appl Biochem 40: 107-111.

GUPTE MD AND KULKARNI PR. 2002. A study of antifungal antibiotic production by Streptomyces chattanoogensis MTCC 3423 using full factorial design. Lett Appl Microbiol 35: 22-26.

Hasegawa S, MEguro A, SHIMIzU M, Nishimura T AND KUNOH H. 2006. Endophytic actinomycetes and their interactions with host plants. Actinomycetologica 20: 7281.

KNOWLES JR. 1970. On the mechanism of action of pepsin. Philos Trans Royal Soc B 257: 135-146.

MonRoe S AND POLK R. 2000. Antimicrobial use and bacterial resistance. Curr Opin Microbiol 3: 496-501.

Oliveira DV, Silva T, ZANin JG, NACHTIGALl G, MEdeiros AW, Frazzon APG AND VAN DER SAND ST. 2012. Qualidade da água e identificação de bactérias Gram-negativas isoladas do Arroio Dilúvio, Porto Alegre, Rio Grande do Sul, Brasil. Evidência 12: 51-62.
OLIVEIRA FC. 2004. Produção, caracterização, purificação parcial e aplicação de um peptídeo antimicrobiano produzido por Bacillus licheniformis P40. Dissertation. Universidade Federal do Rio Grande do Sul, Porto Alegre, Rio Grande do Sul, Brasil. Volume 1, p. 120. (Unpublished).

OliVEIRA MF, Silva MG AND VAN DER SAND S. 2010. Anti-phytopathogen potential of endophytic actinobacteria isolated from tomato plants (Lycopersicon esculentum) in southern Brazil, and characterization of Streptomyces sp. R18(6), a potential biocontrol agent. Res Microbiol 161: 565-572.

PAGÈS J, JAMES CE AND WINTERHALTER M. 2008. The porin and the permeating antibiotic: a selective diffusion barrier in Gram-negative bacteria. Nature Rev Microbiol 6: 893903.

PEI J, YUAN Y AND YUE T. 2013. Primary characterization of bacteriocin paracin $\mathrm{C}$ e A novel bacteriocin produced by Lactobacillus paracasei. Food Control 34: 168-176.

PRABAVATHY VR, MATHIVANAN N AND MURUGESAN K. 2006. Control of blast and sheath blight diseases of rice using antifungal metabolites produced by Streptomyces sp. PM5. Biol Control 39: 313-319.

SELVIN J, SHANMUGHAPRIYA S, GANDHIMATHI R, KIRAN GS, RAVJI TR, NATARAJASEENIVASAN K AND HEMA TA. 2009. Optimization and production of novel antimicrobial agents from sponge associated marine actinomycetes Nocardiopsis dassonvillei MAD08. Appl Microbiol Biotechnol 83: 435-445.

Sosio M, Bossi E, BIANCHI A AND DONADIO S. 2000. Multiple peptide synthetase gene clusters in Actinomycetes. Molec Gen Genet 264: 213-221.

SUJATHA P, RAJU KVVSNB AND RAMANA T. 2005. Studies on a new marine streptomycete BT-408 producing polyketide antibiotic SBR-22 effective against methicillin resistant Staphylococcus aureus. Microbiol Res 160: 119126.

SUNDSFJORD A, SimONSEN G, HALDORSEN BC, HAAHEIM H, HJELMEVOll S, LiTTAUER P AND DAHL KH. 2004. Genetic methods for detection of antimicrobial resistance. Acta Pathol Microbiol Immunol Scand 112: 815-37.

WEBBER MA AND PIDDOCK LJV. 2003. The importance of efflux pumps in bacterial antibiotic resistance. $\mathrm{J}$ Antimicrob Chemother 51: 9-11.

Williams ST, GOODFELlOW M AND ALDERSON G. 1989. Genus Streptomyces Waksman and Henrici 1943, 339. In: Williams ST, Sharpe ME and Halt JG (Eds), Bergey's Manual of Systematic Bacteriology, Williams \& Wilkins, Baltimore, p. 2452-2492.

\section{SUPPLEMENTARY MATERIAL}

TABLE SI - Susceptibility profiles of Gram-negative bacteria isolated from environmental and clinical samples challenged with the antimicrobials chosen for the assay. Dishes were incubated at $35^{\circ} \mathrm{C}$ for $24 \mathrm{~h}$. 